\title{
The effects of explant rotation, medium types, JA and GA 3 additions on in vitro microtuber production from potato (Solanum tuberosum L.)
}

\section{Seray KENAR ${ }^{1}$, Gökçen BAYSAL FURTANA ${ }^{2}$, Șeküre Şebnem ELLİALTIOĞLU ${ }^{3}$, Rukiye TIPIRDAMAZ ${ }^{4 *}$}

\author{
${ }^{1,4}$ HacettepeUniversity, Faculty of Science, Department of Biology, Beytepe, Ankara \\ ${ }^{2}$ Gazi University, Faculty of Science, Department of Biology, Beşevler, Ankara \\ ${ }^{3}$ Ankara University, Faculty of Agriculture, Department of Horticulture, Dışkapı, Ankara \\ *Corresponding author: tuz@ hacettepe.edu.tr
}

\begin{abstract}
This study investigates the effects on the in vitro microtuber formations of Solanum tuberosum L. cv. Marfona species, effected by the direction of planting the explants (horizontal or vertical), the type of medium (solid or two-phase), adding Jasmonic acid (JA) (0.0, $10 \mathrm{ng} / \mathrm{L}, 1 \mu \mathrm{g} / \mathrm{L}$ and $0.2 \mathrm{mg} / \mathrm{L})$ and Gibberellic acid (GA 3$)(0.0$ and $0.2 \mathrm{mg} / \mathrm{L})$. The cultures were incubated in a climate chamber at $22-25^{\circ} \mathrm{C}$, and were subjected to a light intensity of $145 \mu \mathrm{mol} \mathrm{m}^{-2} \mathrm{~s}^{-1}$ for 8 hours in light and 16 hours in dark photoperiods (short day) for 4-6 weeks. Microtuber production was inhibited when GA 3 was added. The maximum number of microtubers was observed when the explants were planted vertically and were grown in two-phase medium which did not contain $\mathrm{GA}_{3}$ and had $10 \mathrm{ng} / \mathrm{L} \mathrm{JA}$ present. It was determined that two-phase medium with $0.2 \mathrm{mg} / \mathrm{L} \mathrm{JA}$ but without $\mathrm{GA}_{3}$ was the most favourable medium for tuber growth (for both height and width). The best microtuber formation on single node explants were observed to occur in the short day photoperiod (8 hours light/16 hours dark) in a two-phase medium that contained $0.2 \mathrm{mg} / \mathrm{L} \mathrm{JA}$ without the addition of GA3. The results shows that the effect caused by JA works antagonistically with that of $G_{3}$ thus causing the resulting microtuber formation observed.
\end{abstract}

Keywords—Potato, In vitro Microtuberization, Two-Phase Medium, Jasmonic Acid, GA.

\section{INTRODUCTION}

The potato (Solanum tuberosum L.) is the fourth most important vegetable after rice, wheat, and corn in food and industry amongst the food sources for the world's population [1, 2]. When potato tubers are grown by vegetative propagation using conventional methods, the viruses on the main plant are easily transferred on to the new vegetative organs and tubers and causes serious damage to potato production. Due to seed tuber growth being significantly affected by environmental conditions, and that the possibility of disease becomes high in addition to high costs, microtubers are emphasized as an alternative seed source [3]. The microtubers that are produced from seedlings with no viral infections that were obtained from meristem cultures and propagated in vitro are considered to have significant advantages in potato seed production.

The success of in vitro microtuber production in the studies conducted in this field is based on a series of factors. Amongst these, nutrient media solutions, the chemicals used (like activated charcoal), sucrose concentration, growth regulators (such as Gibberellic acid, Jasmonic acid) and temperature, environmental factors like light intensity and genotype factors can be included [4-12]. In literature, it is emphasized that due to the plant growth regulators Gibberellic acid $\left(\mathrm{GA}_{3}\right)$, $\mathrm{Abscisic}$ acid (ABA), Ethylene, (2-chloroethyl) trimethylamonium chloride (CCC), and Jasmonic acid (JA) acting on each other and on environmental factors they are effective on the formation and development of vegetative storage organs like tubers [13-16]. The physiological mechanisms and their related hormones that determine potato tuber growth and development are still not fully known.

The gibberellins that are effective in many physiological processes, including plant stem development, seed germination, breaking of bud dormancy, and fruit growth, also effect the development of potato tubers. Environmental factors, like photoperiod and temperature regulate gibberellin biosynthesis [15].

In recent years, the effect of Jasmonic acid and methyl esters on tuber stimulation has been the focus of studies [17-19]. In addition to acting as a signal molecule for activating an immune response in case of pathogen invasions, JA also acts as a regulator for many physiological and developmental (such as root development, tuberization, ageing, and pollen 
development) processes. Jasmonates are also potential stimulators for the expression of vegetative storage protein genes [20]. It is also reported that JA's are effective during in vitro microtuberization in addition to playing an important role in the development of vegetative storage organs [16, 19, 21-24]. However, JA's influence on microtuber development and its relationship with other growth regulators are still not fully elucidated. In the studies conducted, the time taken for microtuber development, the medium conditions for growing microtubers and which hormones, chemicals etc. need to be applied in what doses could not be fully determined [18, 19, 22, 25-27]. To include JA when commercially producing microtubers, more information is needed on the effect of this substance on tuberization and its relationship with other hormones.

In this study, the relationship between the planting of explants (either horizontally or vertically), the type of medium (either solid or two-phase), the addition of Jasmonic acid $(0.0,10 \mathrm{ng} / \mathrm{L}, 1 \mu \mathrm{g} / \mathrm{L}$ and $0.2 \mathrm{mg} / \mathrm{L})$, and Gibberellic acid $(0.0$ and 0.2 $\mathrm{mg} / \mathrm{L}$ ) into the media and how they affect the development of microtubers growing in vitro on the economically valuable Solanum tuberosum L. cv. Marfona is investigated.

\section{MATERIALS AND METHODS}

The study was conducted in four stages: The $S$. tuberosum tuber shoots in vivo, in vitro shoot tip cultures, micropropagation, and microtuberization. For the purpose of shoot development, the potato tubers belonging to the Marfona variety are first washed under tap water, then they are placed in a $15 \%$ commercial sodium hypochloride $(\mathrm{NaOCl})$ solution and left there for 20 minutes. They are then washed with distilled water 3 times [28] so that surface sterilization can occur. The tubers that had there surfaces disinfected are then planted into a pot filled with perlite and left to grow in a climate chamber that has a temperature of 30-35 ${ }^{\circ} \mathrm{C}, 60-65 \%$ humidity, a light intensity of $145 \mu \mathrm{mol} \mathrm{m} \mathrm{s}^{-2}$, and left for photoperiods of 16 hours in light and 8 hours in dark [29]. After 4 weeks, successfully grown shoots were obtained (Figure 1).

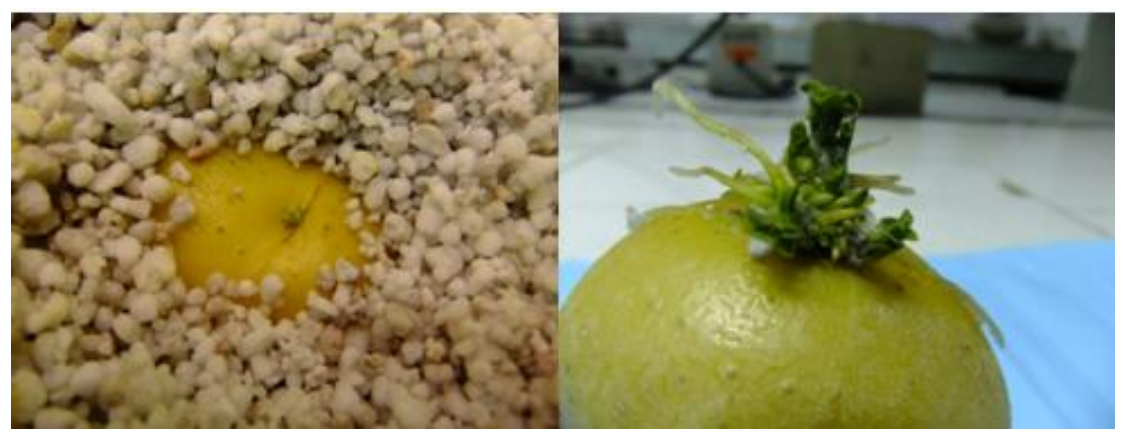

(a)

(b)

\section{FIGURE 1. SHOOT DEVELOPMENT ON TUBERS a) AFTER 1-2 WEEKS, b) AFTER 3-4 WEEKS}

To produce a shoot tip culture, the shoot tips obtained from potato tubers were placed in a $70 \%$ alcohol solution and shaken for 1 minute. Two drops of Tween-20 were then added and left to wait in a 10\% $\mathrm{NaOCl}$ solution for 7-8 minutes, after which the shoot tips were washed with distilled water 3 times for sterilization [18-28]. Shoot tip explants obtained from sterilized shoots were then planted in a modified Murashige and Skoog (MS) medium [30]. Different references [31, 32] were used to produce the nutrient media and the final solution consisted of $30 \mathrm{~g} / \mathrm{L}$ sucrose, $7 \mathrm{~g} / \mathrm{L}$ agar, $0.2 \mathrm{mg} / \mathrm{L} \mathrm{GA} 3,0.2 \mathrm{mg} / \mathrm{L} \mathrm{Kinetin}$, $0.2 \mathrm{mg} / \mathrm{L}$ Indole Acetic Acid (IAA), and $100 \mathrm{mg} / \mathrm{L}$ Myo-inositol. The solution was adjusted to have a $5.8 \mathrm{pH}$. Shoot tips were placed in tubes with dimensions of $15 \times 2.5 \mathrm{~cm}$ and cultured in $10 \mathrm{~mL}$ of Modified MS (MMS) in each tube. The cultures were then incubated for 2-2.5 months in a climate chamber that had a temperature of $20-22{ }^{\circ} \mathrm{C}$, and were subjected to a light intensity of $145 \mu \mathrm{mol} \mathrm{m} \mathrm{s}^{-2}$ with 16 hours of light and 8 hours of dark photoperiods [33]. After this period, in vitro potato plantlets were obtained (Figure 2).

Single node explants taken from plantlets obtained from shoot tip cultures were used for micropropagation. The single nodes were planted into tubes of dimensions $15 \times 2.5 \mathrm{~cm}$ that contained $1.0 \mathrm{mg} / \mathrm{L} \mathrm{IAA}$ and $1.0 \mathrm{mg} / \mathrm{L}$ in addition to the MMS nutrient media. The MMS nutrient media was adjusted to have a $5.8 \mathrm{pH}$ and contained $7 \mathrm{~g} / \mathrm{L}$ agar, $30 \mathrm{~g} / \mathrm{L}$ sucrose, $60 \mathrm{mg} / \mathrm{L}$ myoinositol, $0,4 \mathrm{mg} / \mathrm{L}$ thiamine, $1 \mathrm{~g} / \mathrm{L}$ pyridoxine [34]. The cultures were incubated for 4-7 weeks in a controlled climate chamber of $22{ }^{\circ} \mathrm{C}$ with 16 hours of light and 8 hours of dark photoperiods and a light intensity of $145 \mu \mathrm{mol}^{-2} \mathrm{~s}^{-1}$ [31-33]. 


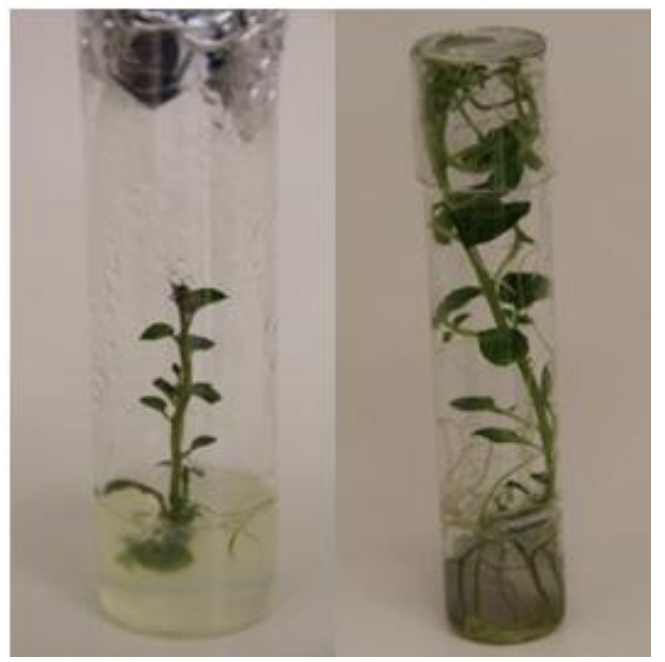

(a)

(b)

FigURE 2. PlantS OBTAINED FROM SHOOT TIP CULTURES a) 3-4 WEEKS AFTER b) 6 WEEKS AFTER

To determine the effects of the medium solution, the planting position (either horizontally or vertically), and type of medium (whether in a solid or two-phase medium), during microtuberization on the development of microtubers, single node explants obtained from plants that were grown in vitro were planted either horizontally or vertically into glass jars of dimensions $6.5 \times 7.5$ that had $50 \mathrm{~mL}$ each of either the solid phasic or two-phase MMS medium (Figure 3). The MMS medium used was made up of JA $(0,10 \mathrm{ng} / \mathrm{L}, 1 \mu \mathrm{g} / \mathrm{L}$ and $0.2 \mathrm{mg} / \mathrm{L}), \mathrm{GA}_{3}(0$ and $0.2 \mathrm{mg} / \mathrm{L})$, and the combination of these in addition to $80 \mathrm{~g} / \mathrm{L}$ sucrose and $7 \mathrm{~g} / \mathrm{L}$ agar. The MMS medium was also adjusted to have a $5.7 \mathrm{pH}[9,26,34]$. Ten explants were planted into each of the 5 jars used and each experiment was repeated 5 times. The cultures were then incubated in a climate chamber for 4-6 weeks at a temperature of $22-25^{\circ} \mathrm{C}$ and a light intensity of $145 \mu \mathrm{mol} \mathrm{m}^{-2} \mathrm{~s}^{-1}$ during an 8 hours light and 16 hours dark photoperiod (short day) [36]. At the end of the incubation period, the number of single nodes obtained from explants, the number of explants from which microtubers were obtained, explant yield (number of explants from which microtubers were obtianed/total number of explants), and the microtuber yield (number of microtubers/total number of explants) were determined for each group. The data was shown as percentages (\%) in a chart.

The statistical analysis of the microtuber numbers and weights were conducted by using the SPSS packet programme. According to variance analysis and statistical test results, each variable was calculated to have a least significant difference (LSD) value between the significant $1 \%$ and $5 \%$ percentage value range. To compare of the groups, Oneway-ANOVA were used variance analysis and were followed by the Duncan's Multiple Range Test for comparing data in individual groups as well as between groups [37].

\section{RESULTS AND DISCUSSION}

The results of the effect of the direction of explant planting (either horizontally or vertically) (Figure 3), type of medium (solid and two-phase) (Figure 3), medium composition [JA (0,10 ng/L, $1 \mu \mathrm{g} / \mathrm{L}$ and $0.2 \mathrm{mg} / \mathrm{L}$ ) and $\mathrm{GA}_{3}(0$ and $0.2 \mathrm{mg} / \mathrm{L})$ ] on microtuber development from single-node potato explants are summarized in Table 1. It was observed that the effect and relationships of the type of medium, the direction in which the explants were planted, and medium composition (JA and $\left.\mathrm{GA}_{3}\right)$ were significant $(\mathrm{p}<0.05)$.

Table 1 shows that in the control group and those that had JA in their medium microtuber development had occurred, while no development was observed when $\mathrm{GA}_{3}$ was present in the medium. Therefore, it was concluded that $\mathrm{GA}_{3}$ should not be present in media prepared for microtuber development. It was observed that the relationship between explant yield (number of explants from which microtubers were obtained/total number of explants) and microtuber yield (number of microtubers/total number of explants) generally increased in a proportional way. Accordingly, it was shown that the twophase groups [two-phase-0.2 mg/L JA (36.53\%), two-phase-1 $\mu \mathrm{g} / \mathrm{L} \mathrm{JA} \mathrm{(45.28 \% ),} \mathrm{and} \mathrm{two-phase-10} \mathrm{ng/L} \mathrm{JA} \mathrm{(44.4 \% )]}$ which gave a high microtuber percentage yield also gave a high percentage yield of the explants $(30.76 \%, 28.3 \%$, and $38.09 \%$ respectively) which the microtubers were obtained from. It was also observed that two-phase-control (9.09\%), Horizontal-10 ng/L JA + $0.2 \mathrm{mg} / \mathrm{L} \mathrm{GA}_{3}(6.84 \%)$, and Vertical-10 ng/L JA + $0.2 \mathrm{mg} / \mathrm{L} \mathrm{GA}_{3}(10.76 \%)$ medium groups which resulted in low microtuber yields additionally generated low explant percentage yields $(7.27 \%, 5.47 \%, 6.15 \%$ respectively). 


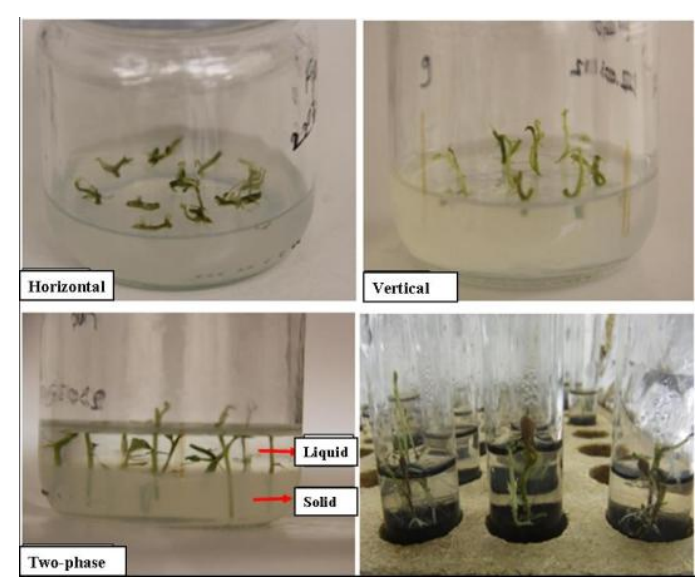

\section{FIGURE 3. THE PLANTING DIRECTION OF SINGLE NODE EXPLANTS}

Highest tuber yields were observed in two-phase- $1 \mu \mathrm{g} / \mathrm{L} \mathrm{JA}$, two-phase- $10 \mathrm{ng} / \mathrm{L} \mathrm{JA}$, and two-phase $-0.2 \mathrm{mg} / \mathrm{L} \mathrm{JA}$ media groups with percentage yield results being $45.28 \%, 44.4 \%$, and $36.53 \%$ respectively. Therefore, it was concluded that twophase media were more suitable for microtuber development.

When the microtuber weights in Table 1 are analyzed, it was observed that microtuber weight, medium composition, and direction of planting of explants had a significant relationship $(\mathrm{p}<0.05)$. The highest values obtained with respect to microtuber weight were $176 \mathrm{mg}, 118 \mathrm{mg}$, and $97 \mathrm{mg}$ for two-phase-control, two-phase- $0.2 \mathrm{mg} / \mathrm{L} \mathrm{JA}$, and vertical- $0.2 \mathrm{mg} / \mathrm{L}$ JA media groups and planting directions respectively. The effects of horizontal and vertical planting directions on microtuber weight and microtuber yield was not significant.

TABLE 1

DATA SHOWING THE EFFECTS OF MEDIA COMPOSITION AND PLANTING DIRECTION OF SEEDLINGS ON MICROTUBER DEVELOPMENT

\begin{tabular}{|c|c|c|c|c|c|c|}
\hline $\begin{array}{l}\text { Planting } \\
\text { Direction }\end{array}$ & JA & $\begin{array}{c}\mathbf{G A}_{3} \\
(\mathbf{0 . 2} \\
\mathrm{mg} / \mathrm{L})\end{array}$ & $\begin{array}{c}\text { Total } \\
\text { explant } \\
\text { number }\end{array}$ & $\begin{array}{l}\text { The number of explants } \\
\text { from which microtubers } \\
\text { were obtained and } \\
\text { explant yield (\%) }\end{array}$ & $\begin{array}{l}\text { The number of } \\
\text { microtubers and } \\
\text { microtuber yield } \\
(\%)\end{array}$ & $\begin{array}{c}\text { Average } \\
\text { Microtuber } \\
\text { weight (mg) }\end{array}$ \\
\hline Horizontal & \multirow{3}{*}{11} & - & 66 & 0 & 0 & 0 \\
\hline \multirow{2}{*}{$\begin{array}{c}\text { Vertical } \\
\text { Two-phase } \\
\end{array}$} & & - & 70 & 0 & 0 & 0 \\
\hline & & - & 55 & $4(7.27 \%)$ & $5(9,09 \%)$ & $176 \pm 57 c^{*}$ \\
\hline \multirow{2}{*}{ Horizontal } & \multirow{6}{*}{ 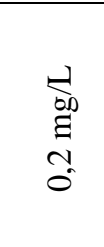 } & - & 64 & $12(18,75 \%)$ & $13(20,31 \%)$ & $37 \pm 9 \mathbf{a}$ \\
\hline & & + & 80 & 0 & 0 & 0 \\
\hline \multirow{2}{*}{ Vertical } & & - & 68 & $16(23,52 \%)$ & $18(26,47 \%)$ & $97 \pm 26 \mathbf{a b}$ \\
\hline & & + & 93 & 0 & 0 & 0 \\
\hline \multirow{2}{*}{ Two-phase } & & - & 52 & $16(30,76 \%)$ & $19(36,53 \%)$ & $118 \pm 26$ bc \\
\hline & & + & 0 & 0 & 0 & 0 \\
\hline \multirow{2}{*}{ Horizontal } & \multirow{6}{*}{$\underset{00}{\stackrel{000}{=}}$} & - & 48 & $12(25 \%)$ & $15(31,25 \%)$ & $35 \pm 8 \mathbf{a}$ \\
\hline & & + & 72 & 0 & 0 & 0 \\
\hline \multirow{2}{*}{ Vertical } & & - & 40 & $6(13,04 \%)$ & $8(20 \%)$ & $45 \pm 7 \mathbf{a}$ \\
\hline & & + & 64 & 0 & 0 & 0 \\
\hline \multirow{2}{*}{ Two-phase } & & - & 53 & $15(28,3 \%)$ & $24(45,28 \%)$ & $55 \pm 14$ ab \\
\hline & & + & 30 & 0 & 0 & 0 \\
\hline \multirow{2}{*}{ Horizontal } & \multirow{6}{*}{$\begin{array}{l}\underset{00}{0} \\
\stackrel{0}{0} \\
0\end{array}$} & - & 69 & 0 & 0 & 0 \\
\hline & & + & 73 & $4(5,47 \%)$ & $5(6,84 \%)$ & $24 \pm 5 \mathbf{a}$ \\
\hline \multirow{2}{*}{ Vertical } & & - & 69 & 0 & 0 & 0 \\
\hline & & + & 65 & $4(6,15 \%)$ & $7(10,76 \%)$ & $32 \pm 9 \mathbf{a}$ \\
\hline \multirow{2}{*}{ Two-phase } & & - & 63 & $24(38,09 \%)$ & $28(44,4 \%)$ & $38 \pm 8 \mathbf{a}$ \\
\hline & & + & 41 & 0 & 0 & 0 \\
\hline Horizontal & & + & 66 & 0 & 0 & 0 \\
\hline Vertical & & + & 70 & 0 & 0 & 0 \\
\hline Two-phase & & + & 41 & 0 & 0 & 0 \\
\hline \multicolumn{3}{|c|}{ TAL } & 1412 & $114(8,07 \%)$ & $142(10,05 \%)$ & $49 \pm 5$ \\
\hline
\end{tabular}

*Means followed by the different letter in the same column are significantly different by Duncan's test $(P \leq 0.05)$. 
In the experiment in which the effects of explant direction when planting, the type of medium, and the $\mathrm{JA}-\mathrm{GA}_{3}$ effects on microtuber development were investigated, it was found that the highest microtuber yield (45.28\%) resulted from the twophase-1 $\mu \mathrm{g} / \mathrm{L}$ JA group. The highest value for microtuber weight was found to be approximately $176 \mathrm{mg}$ in the KC (twophase-control) group. However, when all the data, converted to a common denominator, were analyzed in addition to considering the criteria for using microtubers as potato seeds, it was deduced that the AOC (two-phase- $0.2 \mathrm{mg} / \mathrm{L} \mathrm{JA}$ ) application resulted in high values in regard to microtuber yield and microtuber weight (Microtuber yield $=36.53 \%$ and Average Microtuber weight=118 mg) and thus could be more suitable (Figure 4).

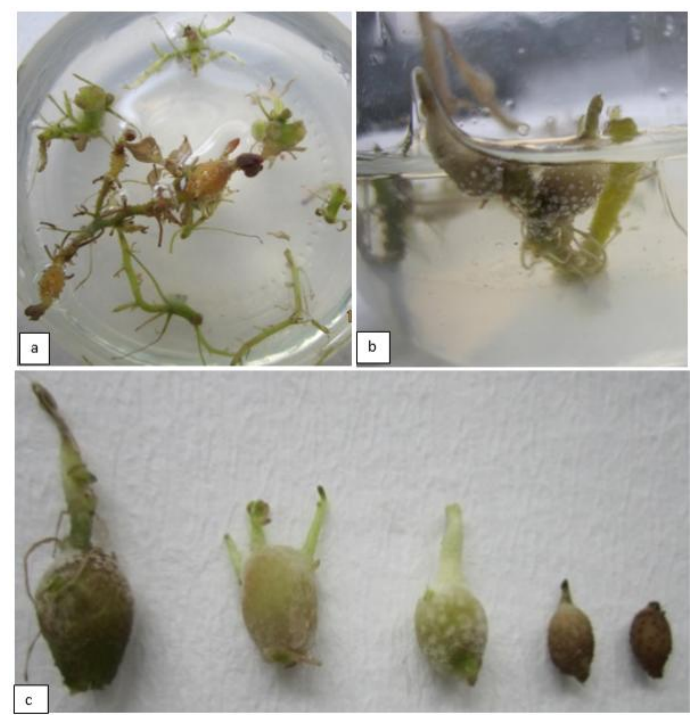

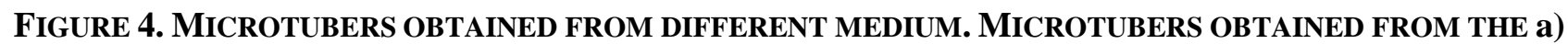

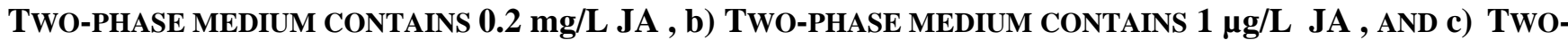
PHASE CONTROL MEDIUM

In this study, the economically valuable Solanum tuberosum L. cv. Marfona was used to develop shoots in vivo, after which in vitro shoot tip cultures were developed. The effects of explant planting direction (horizontal or vertical), media type (solid phase or two-phase), and the addition of Jasmonic acid (0.0,10 ng/L, $1 \mu \mathrm{g} / \mathrm{L}$, and $0.2 \mathrm{mg} / \mathrm{L}$ ), Gibberellic acid $(0.0$ and 0.2 $\mathrm{mg} / \mathrm{L}$ ) were added in to the media, on microtuber developments from the micropropagated plantlets (the shoot tip cultures) were then investigated.

Similarly Gopal et al. [32]'s results, the single nodes taken from plantlets obtained from shoot tip cultures were micropropagated in a MMS medium with $1.0 \mathrm{mg} / \mathrm{L} \mathrm{IAA}$ and $1.0 \mathrm{mg} / \mathrm{L}$ BAP with $7 \mathrm{~g} / \mathrm{L}$ agar, 30g/L sugar, $60 \mathrm{mg} / \mathrm{L}$ myoinositol, $0.4 \mathrm{mg} / \mathrm{L}$ thiamine, $1 \mathrm{~g} / \mathrm{L}$ pyridoxine with a $5.8 \mathrm{pH}$. They were incubated in a climate chamber with a temperature of $22{ }^{\circ} \mathrm{C}$ and a light intensity of $145 \mu \mathrm{mol} \mathrm{m}^{-2} \mathrm{~s}^{-1}$ for 16 hours of light and 8 hours of dark photoperiods.

In our study, whether it were shoot development from in vivo tubers or shoot and plant development in vitro, all were subjected to 16 hours of light and 8 hours of dark (long day) photoperiods. On the other hand, it was determined that during microtuberization, the highest yield of microtuber development occurred when the single node potato explants were subjected to a short day ( 8 hours of light and 16 hours of dark) photoperiod in a two-phase nutrient medium containing 0.2 $\mathrm{mg} / \mathrm{L}$ JA.

Potato tuber development depends on hormonal and environmental factors. Similarly, many relationships between in vitro growth conditions during microtuberization effect microtuber development. Some important factors effecting in vitro microtuberization include; glucose concentration in the medium, the dose of growth regulators added to the medium, type of medium, culture type, and the conditions of the environment in which the potato cultures are incubated in (e.g. temperature, photoperiod) [34, 38-40].

Momena et al. [41] observed the effect of different combination with sucrose and some growth regulators (Kinetin and BAP) on four different potato cultivars and as a result reported that treatment T3 ( $8 \%$ Sucrose $+4 \mathrm{mg} / \mathrm{L}$ Kinetin $+1 \mathrm{mg} / \mathrm{L} \mathrm{BAP}$ ) was the best combination for the investigated cultivars. In another study [42], researchers purposed that to find out the suitable combination of sucrose, growth regulators (benzyladenine and paclobutrazol) and medium type. At the end of the study they 
reported that the best microtuberization rate was obtained in MS/2 liquid medium which include $80 \mathrm{~g} / \mathrm{L}$ sucrose and $0.5 \mathrm{mg} / \mathrm{L}$ IBA.

It was deduced that the carbohydrate source, gibberellins, and anti-gibberellin-like substances and their interactions with each other all effected and regulated potato microtuberization. Harmey [43] determined that gibberellic acid strongly inhibited tuber development but that indole acetic acid and maleic hydrazide induced tuberization. It was also determined that when stem component carbohydrate sources were limited in media with less glucose concentrations, the addition of growth regulators did not induce tuberization.

In another study [44] researchers concluded that GA was an important regulator in tuber development, that ABA conversely stimulated tuber developments, and that sucrose regulated tuber development by controlling GA levels. Vreugdenhil and Sergeeva [45] deduced that internal gibberellin levels were high during condition where tuber development did not occur, and were low during conditions where tuber development did occur. When gibberellin biosynthesis inhibitors (CCC, paclobutrazol, etc.) are used the opposite effect was observed, while the addition of gibberellins in to the medium inhibited tuber development. They also found that gibberellin played a role in cellular mechanisms like cell division, cell widening, and in the lodging of microtubers.

In another study, gibberellin-photoperiod interaction effecting the regulation of microtuber development in potatoes was investigated [46]. It was concluded that S. tuberosum ssp. andigena plants needed short day photoperiods for tuber development and that this process was controlled by gibberellins.

It is indicated that jasmonic acid is carried as a signal for tuber induction and that it plays a role in tuber growth and development [47]. It was observed that when JA is found in the medium, the inhibition effect of $\mathrm{GA}_{3}$ was removed. The reason for this was because it was thought that JA worked antagonistically against the effects of GAs [39, 48].

Abdala et al. [49] determined in their study that the highest concentrations of JA was found in leaves, while during tuber development the highest concentration was found to occur in the roots. During the process of tuber development, the JA concentrations in stolons were found to be drastically reduced.

In our study it was observed that, in regards to medium type and direction of planting the best microtuber yields and microtuber weight was obtained in the two-phase (solid+liquid) nutrient medium. Similarly, it was observed that in various microtuber production methods, the highest yield resulted from two-phase solid propagating-liquid induction systems [9]. In another study [50], the development of microtubers in liquid and solid media were compared, and it was observed that cultures incubated in a liquid medium resulted in microtubers with more weight than those incubated in a solid medium. In a study conducted by Pelacho et al. [51], however, it was found that a half-solid medium resulted in higher tuberization rates and higher tuber weight values than those obtained from liquid media. A reason for the good results, in regards to tuberization, obtained in our study when a two-phase (solid+liquid) medium was used, might be due to the molecules needed for tuberization found in the medium being able to adsorb more readily on to the plant.

It was deduced in our study that the reason for tuber development in media when JA was present while no development was seen with $\mathrm{GA}_{3}$ and $\mathrm{JA}$ together, was because of the antagonistic effect of $\mathrm{GA}_{3}$ on $\mathrm{JA}$.

In a similar study, it was observed that when gibberellins were added externally, it had a negative effect on tuber development, although internal $\mathrm{GA}_{3}$ supported tuber development [45]. Tuber formation and its subsequent development, is a result of cell division and cell growth. Internal $\mathrm{GA}_{3}$ is thought to play a role in these cell divisions [44]. As GA 3 is an inhibitor of the glycoprotein patatin, which is associated with microtuberization, adding $\mathrm{GA}_{3}$ to the external environment makes the concentration levels too high for the inhibition to be tolerated and thus microtuber formation is blocked [52]. Additionally, Jasik and Mantell [26] observed the effect of JA on three types of yam (Dioscorea) and as a results confirmed that JA supported microtuberization. In another study [46], researchers determined that gibberellins participated in the 8 hours light-16 hours dark photoperiod that encouraged potato tuberization, and that their role was as a regulator, showing gibberellins to have a relationship to tuber formation in a negative way.

In our study, the results of the microtuberization experiments showed that when looking at the effects of explant planting direction, medium type, and $\mathrm{JA}-\mathrm{GA}_{3}$ interactions, the highest microtuber yield (45.28\%) was obtained from the two-phase, 1 $\mu \mathrm{g} / \mathrm{L} \mathrm{JA}$ containing medium. In regards to microtuber weight, the highest weight value (176 mg/tuber) resulted from the twophase, control medium. In similar studies $[16,53]$ the researchers obtained a higher number of microtubers with greater 
weight, when JA was added to the medium. In potatoes, tuberization starts with the widening of the sub-apical meristem of stolons and jasmonates, by preventing the longitudinal growth of stolons, stimulate the widening of the sub-apical meristem.

When the criteria for microtubers that will be used as potato seeds was taken into consideration it was deduced from the results obtained in our study that the medium which gave the highest microtuber yield and weight (Microtuber yield $=36.53 \%$ and Avg. Microtuber weight=118mg) was the $0.2 \mathrm{mg} / \mathrm{L} \mathrm{JA}$ two-phase medium (Figure 4).

\section{CONCLUSION}

To summarize the results:

- The best medium type for microtuber formation was a two-phase medium,

- $\mathrm{GA}_{3}$ addition to the medium inhibited microtuber formation,

- JA addition to the medium resulted in positive effects on microtuber formation and this effect resulted from working antagonistically with $\mathrm{GA}_{3}$,

- In regards to $\mathrm{JA}_{-} \mathrm{GA}_{3}$ interaction and medium type, a two-phase medium with $0.2 \mathrm{mg} / \mathrm{L} \mathrm{JA}$ but without any GA was found to be the optimal medium.

In future studies, different substances that encourage tuberization will be beneficial for researching about other and their relationship with photoperiods in developing mechanisms in the production of microtubers.

\section{REFERENCES}

[1] M. S. Zaman, A. Quraishi, G. Hassan, S. Raziuddin Ali, A. Khabir, and N. Gul, "Meristem Culture of potato (Solanum tuberosum L.) for Production of Virus-Free Plantlets", Online J Biol Sci, vol. 1(10), pp. 898-899, 2001.

[2] Ü. Güner, "Ülkemizde Patateslerde Yapılmıș Virüs Hastalıkları ile İlgili Araştırmalar", IV. Ulusal Patates Kongresi Bildiriler Kitabı Özetleri, Website:http://www.patates.gov.tr/download.php?lng=tr, 2013.

[3] M. E. Çalışkan, H. Arıoğlu, N. Kuşman, and S. Çalışkan, "Gerçek Patates Tohumu Teknolojisinin Türkiye'de Verim Potansiyeli ve Uygulanabilirliği”, IV. Ulusal Patates Kongresi Bildiriler Kitabı Özetleri. http://www.patates.gov.tr/download. php?lng=tr, 2006.

[4] G. Hussey, and N.J. Stacey, "Factors Affecting the formation of In Vitro Tubers of Potato (Solanum tuberosum L.)", Ann Bot, vo. 53 , pp. $565-578,1984$.

[5] G. Ortiz-Montiel, and H. Lozoya-Saldana, "Potato Minitubers: Technology Validation in Mexico", Am Potato J, vol. 64, pp. 535-544, 1987.

[6] N. Garner, and J. Blake,"The Induction and Development of Potato Microtubers In Vitro on Media Free of Growth Regulating Substances", Ann Bot, vol. 63: pp. 663-674, 1989.

[7] E. Esendal "Patates”. Ondokuz Mayıs Üniversitesi, Ziraat Fakültesi Yayınları, Samsun, pp. 49, 1990.

[8] C. Er, and S. Uranbey, “Nişasta ve Şeker Bitkileri”, Ankara Üniversitesi Ziraat Fakültesi Yayınları, Ankara, pp. $458,1998$.

[9] S. Beyazova, "Production of Microtubers in Potato (Solanum tuberosum)", Middle East Technical Univ. Dept of Biology, Ms.C Thesis, Ankara, 1999.

[10] G. Öztürk, "Patateste (Solanum tuberosum L.) In Vitro Koșullarda Mikro Yumru Üretimine Farklı Besin Ortamlarının Etkisi”", Ankara Üniversitesi Fen Bilimleri Enstitüsü, Yüksek Lisans Tezi, Ankara, 2003.

[11] FAOSTAT, "Food and Agriculture Organization of the United Nation (FAO) Statistical Data bases", Website: http://www.fao.org, 2010.

[12] K. G. A.Elaleem, R. S. Modawi, and M. M. Khalafalla, "Microtuber Induction of Two Potato (Solanum tuberosum L.) Varieties Namely, Almera and Diamant", Int Res J Biol Sci, vol. 4(3), pp. 84-89, 2015.

[13] A. Zaib-Un Nissa, and A. Rafiq, "Effect of ABA and GA 3 on Tuberization and Some Chemical Constituent of Potato", Plant Cell Physiol, vol. 21, pp. 1343-1346, 1980.

[14] A. K. Bhatia, M. L. Pandita, and S. C. Khurana, "Plant Growth Substances and Sprouting Conditions: II. Effect on Tuber Yield and Multiplication Rate in Seed Potato Production", J Indian Potato Assoc, vol. 19, pp. 154-156, 1992.

[15] S. K. Kim, J. T. Kim, S. W. Jang, S. C. Lee, B. H. Lee, and I. J. Lee, "Exogenous Effect of Gibberellins and Jasmoate on Tuber Enlargement of Dioscorea opposite", Agron Res, vol. 3, pp. 39-44, 2005.

[16] J. Jasik, and G. J. Klerk, "Effect of Methyl Jasmonate on Morphology and Dormancy Development in Lily Bublets Regenerated In Vitro", J Plant Growth Regul, vol. 25, pp. 45-51, 2006.

[17] K. Pruski, P. Duplessis, T. Lewis, T. Astatkie, J. Nowak, and P. C. Struik, "Jasmonate effect on in vitro tuberization of potato (Solanum tuberosum L.) cultivars under light and dark conditions", Potato Res, vol. 44, pp. 315-325, 2002.

[18] Z. J. Zhang, H. Z. Li, W. J. Zhou, Y. Takeuchi, and K. Yoneyama, "Effect of 5-Amino Levulinic Acid on Development and Salt Tolerance of Potato (Solanum tuberosum L.) Microtubers In Vitro", J Plant Growth Regul, vol. 49, pp. 27-34, 2006. 
[19] U. P. Rayirath, R. R. Lada, C. D. Caldwell, S. K. Asideu, and K. J. Sibley, "Role of Ethylene and Jasmonic Acid on Rhizome Induction and Growth in Rhubarb (Rheum rhabarbaum L.)", Plant Cell Tiss Org Cult, vol. 105, pp. 253-263, 2011.

[20] O. Lorenzo, and R. Solano, "Molecular Players Regulating the Jasmonate Signaling Network", Curr Opin Plant Biol, vol.8, pp. 532$540,2005$.

[21] J.H. Van den Berg, and E.E. Ewing, "Jasmonates and Their Role in Plant Growth and Development with Special Reference to The Control of Potato Tuberization: A Review”, Am Potato J, vol. 68, pp. 781-794, 1991.

[22] Y. Koda, Y. Kikuta, H. Tazaki, Y. Tsujino, S. Sakamura, and T. Yoshihara, "Potato Tuber Inducing Activities of Jasmonicacid and Related Compounds", Phytochemistry, vol. 30, pp. 1435-1438, 1991.

[23] A. M. Pelacho, and A.M. Mingo-Castel AM, "Jasmonic Acid Induces Tuberization of Potato Stolon Cultured In Vitro", Plant Physiol, vol. 97, pp. 1253-1255, 1991.

[24] M. Ravinkar, B. Vilhar, and N. Gogala, "Stimulatory Effects of Jasmonic Acid on Potato Node and Protoplast Culture", J Plant Growth Regul, vol. 11, pp. 29-33, 1992.

[25] W. Zhang, C. Curtin, M. Kikuchi, andC. Franco, "Integration of Jasmonic Acid and Light Irradiation for Enhancement of Enthocyanin Viosynthesis in Vitis (Vinifera suspension) Cultures”, Plant Sci, vol. 162, pp. 459-468, 2002.

[26] J. Jasik, and S.H. Mantell, "Effects of Jasmonic Acid and its Methyl Ester on In Vitro Microtuberization of Three Food Yam (Dioscorea) Species", Plant Cell Rep, vol. 19, pp. 863-867, 2000.

[27] N. Debeljak, M. Regvar, K.W. Dixon, and K. Sivasithamparam, ”Induction of Tuberisation In Vitro with Jasmonic Acid and Sucrose in An Australian Terrestrial Orchid, Pterostylis sanguinea", J Plant Growth Regul, vol. 36, pp. 253- $260,2002$.

[28] M. Babaoğlu, E. Gürel, and S. Özcan,“Bitki Biyoteknolojisi”, S.Ü. Vakfı Yayınları, 2001, Konya.

[29] M. J. Moeinil, M. Armin, M. R. Asgharipour, and S.K. Yazdi, "Effects of Different Plant Growth Regulators and Potting Mixes on Micro-Propagation and Mini-Tuberization of Potato Plantlets", Adv Environ Biol, vol. 5(4), pp. 631-638, 2011.

[30] T. Murashige, and F. Skoog, "A Revised Medium for Rapid Growth and Bioassays with Tobacco Tissue Cultures", Physiol Plantarum, vol. 15, pp. 473-497, 1962.

[31] R. S. Sangwan, C. Detrez, and B. S. Sangwan-Norreel, "In Vitro Culture of Shoot-Tip Meristems in Some Higher Plants", Symposium on In Vitro Problems Related to Mass Propagation of Horticultural Plants, 1987.

[32] J. Gopal, J. L. Minocha, and H. S. Dhaliwal, “Microtuberization in Potato (Solanum tuberosum L.)”, Plant Cell Rep, vol. 17, pp. 794$798,1998$.

[33] K. Grigoriadou, and N. Leventakis, "Large Scale Commercial Production of Potato Minitubers, using In Vitro Techniques", Potato Res, vol. 42, pp. 607-610, 1999.

[34] G. A. Romanov, N. P. Aksenova, T. N. Konstantinova, S. A. Golyanovskaya, J. Kossman, and L. Willmitzer, "Effect of Indole-3Acetic Acid and Kinetin on Tuberisation Parameters of Different Cultivars and Transgenic Lines of Potato In Vitro", J Plant Growth Regul, vol. 32, pp. 245-251, 2000.

[35] R. Estrada, P. Tovar, and J. H. Dodds, "Induction of In Vitro Tubers in A Broad Range of Potato Genotypes", Plant Cell Tiss Org Cult, vol. 7, pp. 3-10, 1986.

[36] Z. Yıldırım, and E. Tugay, "Beş Patates Genotipinin In Vitro Koşullarda Mikro Yumru Oluşturması Üzerinde Bir Araştırma", Ege Üniversitesi Ziraat Fakültesi Dergisi, vol. 39(1), pp. 41-45, 2002.

[37] R. Sokal, and F. J. Rohlf, "Biometry. The Principles and Practice of Statistics in Biological Research", Third Edition, WH Freeman and Co, 1995, New York, USA.

[38] E. E. Ewing, "The Role of Hormones in Potato (Solanum tuberosum L.) Tuberization", In: Davies, P.J., (ed) Plant Hormones, Physiology, Biochemistry and Molecular Biology, Dordrecht: Kluwer Academic Publishers, 1995, pp. 698-724.

[39] G. Castro, A. Guillermina, C. Agüero, and R. Tizio, "Interaction between Jasmonic and Gibberellic Acids on In Vitro Microtuberization of Potato Plantlets", Potato Res, vol. 43, pp. 83-88, 2000.

[40] Z. A. AL-Hussaini, S. H. A. Yousif, and S. A. AL-Ajeely, "The Role of Sucrose and Light Duration on In Vitro Tuberization for Two Cultivars of Potato Solanum tuberosum L.”, Int J Current Microbiol App Sci, vol. 4(2), pp. 277- 283, 2015.

[41] K. Momena, R. Adeeba, H. Mehraj, A. F. M. Jamal Uddin, S. Islam, and L. Rahman, "In Vitro Microtuberization of Potato (Solanum Tuberosum L.) Cultivar through Sucrose and Growth Regulator”, J Biosci Agricult Res, vol. 02(02), pp. 76-82, 2014.

[42] F. Mani, M. Mhamdi, T. Bettaieb, and C. Hannachi, "Shoot Regeneration, Micropropagation and Microtuberization of Potato (Solanum tuberosum L.) Cultivars”, J New Sci, vol. 7(2), pp. 10-18, 2014.

[43] M. A. Harmey, H. Ikuma, and W. D. Bonner, "Near Ultra-Violet Spectrum of White Potato Mitochondria", Nature, vol. 209, pp. 174-175, 1966.

[44] D. Vreugdenhil, X. Xu, and A. A. M. Lammeren, “Cell Division and Cell Enlargement during Potato Tuber Formation”, J Exp Bot, vol. 49(320), pp. 573-582, 1998

[45] D. Vreugdenhil, and L. I. Sergeeva, "Gibberellins and Tuberization in Potato”, Potato Res, vol. 42, pp. 471-481, 1999.

[46] J. F. Martinez-Garcia, J. L. Garcia-Martinez, J. Bou, and S. Prat, "The Interaction of Gibberellins and Photoperiod in The Control of Potato Tuberization”, J Plant Growth Regul, vol. 20, pp. 377-386, 2002.

[47] S. D. Jackson, and L. Willmitzer, "Jasmonic Acid Spraying Does Not Induce Tuberisation in Short-Day-Requiring Potato Species Kept in Non-Inducing Conditions", Planta, vol. 194(2), pp. 155-159, 1994.

[48] S. D. Jackson, "Multiple Signaling Pathways Control Tuber Induction in Potato", Plant Physiol, vol. 119, pp. 1-8, 1999.

[49] G. Abdala, G. Castro, O. Miersch, and D. Pearce, "Changes in Jasmonate and Gibberellin Levels during Development of Potato Plants (Solanum tuberosum)", J Plant Growth Regul, pp. 1-6, 2000. 
[50] G. Rosell, F. G. Bertoldi, and R.Tizio, "In Vitro Mass Tuberisation as A Contribution to Potato Micropropagation”, Potato Res, vol. 30(1), pp. 111-116, 1987.

[51] A. M. Pelacho, L. Martin-Closas, and J. L. I. Sanfeliu, "In Vitro Induction of Potato Tuberization by Organic Acids", Potato Res, vol. 42, pp. 585-591, 1999.

[52] D. J. Hannapel, J. C. Miller, and W. D. Park, "Regulation of Potato Tuber Protein Accumulation by Gibberellic Acid", Plant Physiol, vol. 78, pp. 700-703, 1985.

[53] K. Takahashi, K. Fujino, Y. Kikuta, and Y. Koda, "Expansion of Potato Cells in Response to Jasmonic Acid”, Plant Sci, vol. 100, pp. 3-8, 1994. 